\title{
Potent infection reservoir of crayfish plague now permanently established in Norway
}

\author{
Trude Vrålstad ${ }^{1,2, *, * *}$, Stein I. Johnsen ${ }^{3, * *}$, Rosa Ferreira Fristad ${ }^{1}$, Lennart Edsman ${ }^{4}$, \\ David Strand ${ }^{1,2}$
}

\author{
${ }^{1}$ Section of Mycology, Norwegian Veterinary Institute, PO Box 750, Sentrum, 0106 Oslo, Norway \\ ${ }^{2}$ Microbial Evolution Research Group (MERG), Department of Biology, University of Oslo, 0316 Oslo, Norway \\ ${ }^{3}$ Norwegian Institute for Nature Research, Fakkelgården, 2624 Lillehammer, Norway \\ ${ }^{4}$ Institute of Freshwater Research, Department of Aquatic Resources, Swedish University of Agricultural Sciences, \\ 17893 Drottningholm, Sweden
}

\begin{abstract}
Noble crayfish Astacus astacus is threatened in Europe due to invasive crayfish carrying the crayfish plague agent Aphanomyces astaci. Norway is among the last countries in which the introduction of non-indigenous crayfish has been limited through strict legislation practices. However, North American signal crayfish Pacifastacus leniusculus were recently discovered in a watercourse that has been repeatedly hit by the plague. We mapped the distribution and relative density (catch per unit effort) of signal crayfish within this lake, and performed agent-specific real-time PCR to estimate the prevalence of $A$. astaci in the population. The resulting length frequencies and relative density estimates clearly demonstrate a well-established signal crayfish population, in which $86.4 \%$ of the analysed individuals were confirmed carriers. The success of detection was significantly higher $(84.1 \%)$ in the crayfish tailfan (i.e. uropods) than in the soft abdominal cuticle (38.4\%), which is commonly used in prevalence studies. We therefore propose tailfan (uropods and telson) as the preferred tissue for studying $A$. astaci prevalence in signal crayfish populations. The likelihood of detecting an $A$. astaci-positive signal crayfish increased significantly with increasing crayfish length. Further, large female crayfish expressed significantly higher PCR-forming units values than large males. In surveys primarily exploring the presence of $A$. astaci-positive individuals in a population, large females should be selected for molecular analyses. Our study demonstrates that a potent crayfish plague infection reservoir, evidently originating from the illegal human introduction of signal crayfish, has permanently been established in Norway.
\end{abstract}

KEY WORDS: Alien crayfish · Signal crayfish abundance $\cdot$ Halden watercourse · Management · Molecular diagnostics · Quantitative PCR

\section{INTRODUCTION}

The noble crayfish Astacus astacus is indigenous to Europe, and represents the only indigenous species of freshwater crayfish in Scandinavia (Souty-Grosset et al. 2006, Holdich et al. 2009). The species is regarded as vulnerable in Europe and endangered in Norway according to the IUCN (Edsman et al. 2010) and Norwegian (Oug et al. 2010) red lists of threatened species, respectively. Signal crayfish Pacifastacus leniusculus are natural hosts for the parasitic oomycete Aphanomyces astaci (Unestam 1972), which is ranked among the world's worst 100 invasive alien species according to the global invasive species database (www.issg.org/ database). Signal crayfish are thus potential chronic carriers of the agent that since the 1860s has caused crayfish plague in Europe, a disease lethal to all freshwater crayfish not of North American origin (Unestam 1972, Alderman et al. 1990, Söderhäll \& Cerenius 1999). Sweden introduced this species on a large scale at the end of the 1960 s as an alternative to the noble crayfish that was not only highly susceptible to $A$. 
astaci infection, but had also suffered severely from the plague for decades in Sweden (Edsman 2004). The legal introduction, along with subsequent illegal stockings of plague-carrying signal crayfish, resulted in numerous crayfish plague outbreaks in indigenous noble crayfish populations. Today, due solely to crayfish plague, $>95 \%$ of the Swedish noble crayfish populations have disappeared, and signal crayfish has become the dominant species of freshwater crayfish in Swedish water bodies (Edsman 2004, Bohman et al. 2006, SoutyGrosset et al. 2006).

In sharp contrast, Norway has never allowed the introduction of non-indigenous crayfish species and was regarded for a long time as one of the only countries in Europe devoid of invasive crayfish. The first record of signal crayfish in Norway was made in 2006 (Johnsen et al. 2007), but the restricted population was eradicated through intensive effort and the support of the Norwegian Food Safety Authority and the Directorate for Nature Management (Sandodden \& Johnsen 2010). Despite the assumed signal-crayfish-free history, Norway has nevertheless experienced repeated outbreaks of crayfish plague. However, compared to Europe in general and Sweden in particular, the crayfish-plague history of Norway is simple and has mainly involved 4 large watercourses close to the Swedish border, including the Halden watercourse (Taugbøl et al. 1993). The underlying causes for these outbreaks remain unknown, but proposed explanations include vectors infested with Aphanomyces astaci spores, such as fishing gear or boats used in Swedish waters, or undiscovered plaguecarrying signal crayfish. In the Halden watercourse, mass mortalities of noble crayfish assumed to be caused by crayfish plague were observed in Lake Øymarksjøen in 1989 (Taugbøl et al. 1993). In 1995, a stocking programme was initiated to reintroduce noble crayfish to the watercourse (Taugbøl 2004). Four years later, natural recruitment was observed at most stocking sites in the watercourse. The disappointment was therefore pronounced when a new outbreak of crayfish plague devastated the re-stocked noble crayfish populations of Lake Øymarksjøen and lakes further downstream during the 2005 season (Vrålstad et al. 2006). However, rapid response from Norwegian Food Safety Authority led to immediate closure of the locks of Ørje that connects Lake Øymarksjøen with the upstream Lake Rødenessjøen (Fig. 1). These locks, built in 1860, represent an important tourist attraction in the Halden canal, and separate the system's lakes with a total of 3 locks and a $10 \mathrm{~m}$ height difference. Their original purpose was to transfer boats from one lake to another, but since 2005 they have served as an efficient infection barrier against upstream spread of the crayfish plague.

The source of crayfish plague infection remained unknown until July 2008, when signal crayfish were

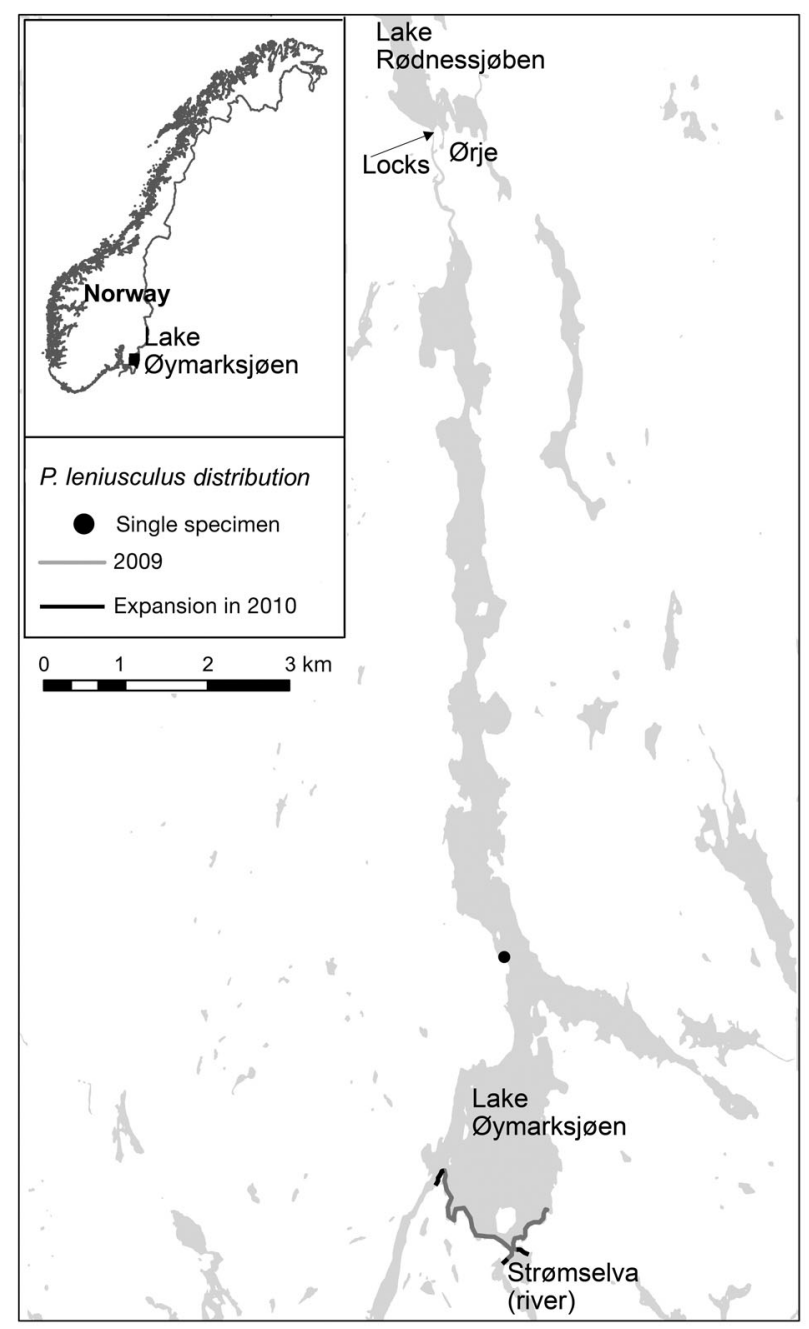

Fig. 1. Map of Lake Øymarksjøen with the main distribution of signal crayfish Pacifastacus leniusculus indicated as a solid gray (2009) and black (2010) line. The distributions are based on trap surveys in 2009 and 2010. (•) Record of a single specimen of signal crayfish

discovered in Lake Øymarksjøen (Johnsen \& Vrålstad 2009). In the present study, we mapped the distribution and relative density of the signal crayfish population, and analysed the carrier status using Aphanomyces astaci-specific real-time (RT) polymerase chain reaction (PCR) (Vrålstad et al. 2009). We present evidence for a well-established signal crayfish population with a high prevalence of $A$. astaci. Implications for management and future challenges are discussed.

\section{MATERIALS AND METHODS}

Crayfish catch. Rumors suggesting that signal crayfish Pacifastacus leniusculus had been introduced to Lake Øymarksjøen led to a small-scale survey of 3 dif- 
ferent sites in the lake with a total effort of 133 trap nights in 2008. In 2009, an extended survey was conducted with a total of 700 trap nights distributed at 32 sites around the shoreline of the entire lake. Traps baited with roach Rutilus rutilus and bream Abramis brama were set in the evening and emptied the following morning. Based on the survey in 2009, the main distribution area of signal crayfish was mapped and identified (see Fig. 1). Of the total 700 trap nights in 2009, an effort of 90 trap nights was distributed within the main distribution area of signal crayfish. The catch per unit effort (CPUE traps ) in 2009 was recorded as the average of 5 chained traps. In an attempt to reduce the density of the signal crayfish population, a fishing project with a total fishing effort of 2221 trap nights was performed in 2010. Since the aim of this project was to drastically reduce the population, the effort was almost exclusively concentrated within the main distribution area of signal crayfish. Here, the $\mathrm{CPUE}_{\text {traps }}$ was recorded as an average of the daily catches. In addition to the trap catches, we sampled (handpicking) crayfish when SCUBA diving in 2009 and 2010. From each individual caught in the trap surveys in 2008 and 2009, and from the SCUBA diving surveys in 2009 and 2010, the total body length was measured to the nearest millimetre from the tip of the rostrum to the end of the tail fan. Individuals from the catch were identified to species in accordance with the identification leaflet by Pöckl et al. (2006).

Molecular diagnostics. In order to test if recorded signal crayfish were carriers of Aphanomyces astaci, 44 individuals from the 2009 sample were subjected to molecular analyses. From each ethanol-preserved crayfish, 3 standardised tissue sub-samples were dissected each time including the proximal joint of 2 anterior walking legs (referred to as L samples), 1 longitudinal half of the soft abdominal cuticle (C), and a three-fifths fraction of the outer part of the crayfish tail fan that, in our case, only included uropod tissue (U; see Fig. 2). Each crayfish individual was carefully examined for melanised spots that may represent a clinical sign of $A$. astaci infection. If black spots were observed, a maximum of 2 spots per crayfish (referred to as S1 and S2) were subjected to further analyses. The crayfish tissue samples were homogenised in CTAB lysis buffer in disposable $2 \mathrm{ml}$ tubes with steel beads (Precellys MK28) on Precellys ${ }^{\circledR} 24$ lysis and homogenisation automated equipment (Bertin Technologies) using the following programme: $6500 \mathrm{rpm}$ for 1 min for 3 sessions with 2 min rest time between the sessions. The samples were frozen at $-80^{\circ} \mathrm{C}$ for minimum 10 min before DNA was extracted according to the CTAB protocol described by Vrålstad et al. (2009). In order to control for potential carry-over contamination, an environmental control and an extraction blank

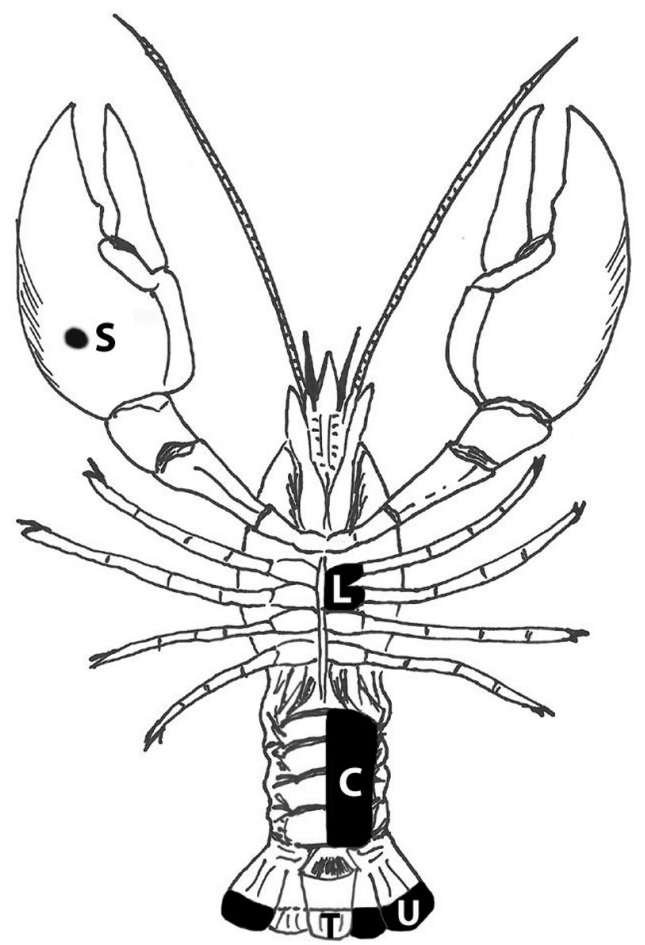

Fig. 2. Pacifastacus leniusculus. Signal crayfish tissue samples that were included in molecular tests (in black). L: inner joint of the 2 posterior proximal walking legs; C: longitudinal half of the soft abdominal cuticle; U: three-fifths of the tail fan (only including uropod tissue; the middle segment, i.e. telson (T), was not analysed in the present study, but is comparable to the uropods); S: melanised spot (S) of the exoskeleton, if present, where a maximum of 2 spots (S1 and S2) were subjected to further analyses

control as described by Vrålstad et al. (2009) were included in the DNA-isolation step and subsequent PCR analyses.

The RT-PCR for specific and quantitative detection of Aphanomyces astaci was performed according to the method described by Vrålstad et al. (2009) using the A. astaci-specific primer-pair AphAstITS39FAphAstITS97R combined with the MGB-TaqMan probe AphAstITS60P. For each PCR run, 4 calibrants consisting of $A$. astaci genomic DNA with known concentrations and PFUs (PCR-forming units) were included to generate a standard curve for quantification of A. astaci in terms of PFU in the unknown crayfish tissue samples. These 4 calibrants corresponded to Standards 2, 4, 6 and 8 described by Vrålstad et al. (2009) and contained an estimated number of PFUs corresponding to $3 \times 4^{9}, 3 \times 4^{7}, 3 \times 4^{5}$ and $3 \times 4^{3}$ (cf. Vrålstad et al. 2009, their Table 3). Each of the unknown samples was included as concentrated $(1 \times)$ and $10 \times$ diluted template in the PCR setup. In the absence of inhibition (corresponding to $\Delta \mathrm{Ct}=3.32$ for the $1 \times$ and $10 \times$ concentrations) absolute quantification 
is possible. However, in the present study, PCR inhibition was commonly observed as a delayed signal or lacking signal in the $1 \times$ concentration. We therefore assigned our results to semi-quantitative agent levels as suggested by Vrålstad et al. (2009), and this semi-quantification relied in all cases on the 10x diluted template concentration. Any detection below LOD (limit of detection), i.e. Agent Level 1 (A1), was regarded as negative.

Statistical methods. Of the individuals that tested negative for Aphanomyces astaci in analysed tissues, all were males. Male signal crayfish $(n=23)$ were therefore used in a binary logistic regression model to test the relationship between the probability of observing an A. astaci-positive signal crayfish and the coefficient of the quantitative predictor, length. Individuals were regarded as infected if one of the tested tissues was positive.

We performed a Mann-Whitney $U$-test on mature signal crayfish ( $\geq 90 \mathrm{~mm}$ in total length) to test if the PFU levels differed between genders. From the survey in 2009, the majority of female signal crayfish matured at lengths $\geq 90 \mathrm{~mm}$. No differences in median length were found between males and females $\geq 90 \mathrm{~mm}(U=102.5, \mathrm{p}=0.948)$.

Chi-squared statistics and odds ratios were used to test the success of different tissues ( $C, L$ and $U$ ) in detecting Aphanomyces astaci-positive individuals. To test if positive tissues of $\mathrm{C}, \mathrm{L}$ and $\mathrm{U}$ differed in PFU levels, we used ANOVA on ranks with an all pairwise comparison procedure (Dunn's method). Due to the relatively small and skewed sample (12 crayfish with spots compared to 32 without), spots were excluded from statistical analyses. Statistical calculations were done in SigmaStat 11.0.

\section{RESULTS}

\section{Distribution and relative abundance of signal crayfish}

A total of 25 signal crayfish Pacifastacus leniusculus were caught in Lake Øymarksjøen in 2008. All specimens were caught within the main distribution that was identified in 2009 (Fig. 1). In 2009 and 2010, the total numbers of signal crayfish caught in baited traps were 188 and 3845, respectively. In 2009, CPUE traps $_{\text {s }}$ within the main distribution area varied between 0.2 and 5.6, with an average of 2.1 signal crayfish per trap night. In 2010, comparable CPUE traps data (from August) varied from 1.5 to 4.3 , with an average of 3.2. The length distribution of signal crayfish caught by

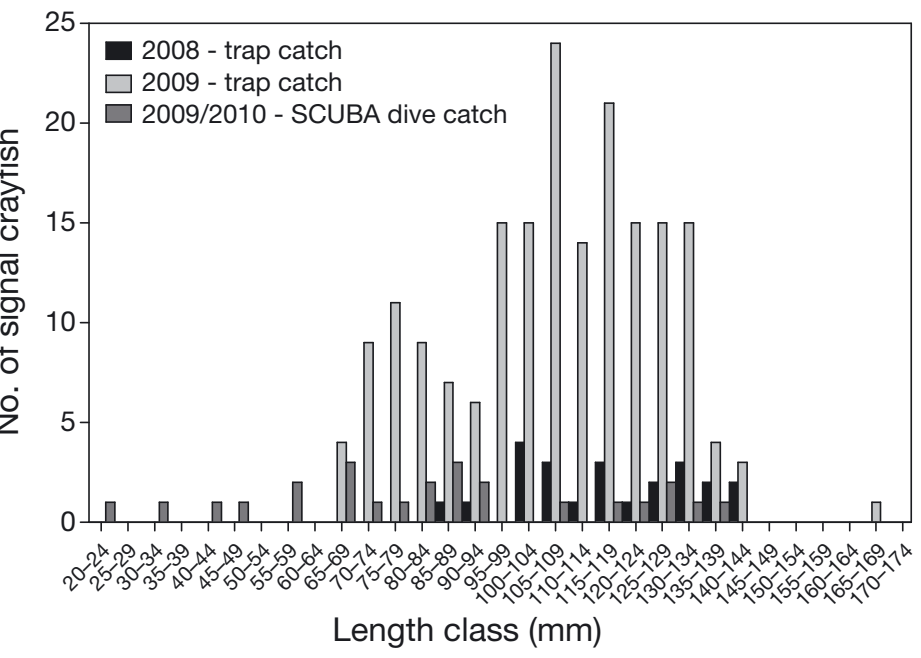

Fig. 3. Pacifastacus leniusculus. Length distribution (total length) of ignal crayfish in Lake Øymarksjøen caught with baited traps in 2008 black bars, $\mathrm{n}=23$ ) and 2009 (light grey bars, $\mathrm{n}=188$ ), and from SCUBA diving in 2009 and 2010 (dark grey bars, $\mathrm{n}=10$ and 15, respectively)

baited traps (2008 and 2009) and SCUBA diving (2009 and 2010) ranged from 20 to $168 \mathrm{~mm}$ (Fig. 3). Compared to 2009, signal crayfish increased their distribution area by about $300 \mathrm{~m}$ on the western side and about 100 m downstream in the Strømselva River (Fig. 1).

\section{Molecular detection and prevalence of Aphanomyces astaci}

Overall, $86.4 \%$ of the crayfish were Aphanomyces astaci-positive in one of the tested tissues, while $31.8 \%$ tested positive for all tissues (Table 1). The 6 individuals $(13.6 \%)$ in which $A$. astaci was not detected were all smaller males with a length $<9 \mathrm{~cm}$, but there were also some small males that were positive. In male signal crayfish, the estimated effect of length as a predictor in the logistic regression model was significant $(Z=4.27$, $p=0.039$ ). It was 2.33 (95\% CI: 1.04 to 5.18$)$ times more likely to observe infected male signal crayfish when the length increased by 1 unit $(10 \mathrm{~mm})$. All females, regardless of size, were positive (Table 1), and, among crayfish $\geq 90 \mathrm{~mm}$, the PFU values were significantly larger in females than in males $(U=57, \mathrm{p}=0,043)$.

The prevalence of Aphanomyces astaci in signal crayfish tissues based on species-specific RT-PCR results is summarised in Fig. 4. The success of detection was high for uropod samples $(84.1 \%)$, moderate for walking-leg samples (59.1\%), and relatively low for soft abdominal cuticle samples (38.6\%; Fig. 4). Compared to walking legs and cuticle, it was respectively 3.66 (95\% CI: 1.34 to $\left.10.02 ; \chi^{2}=5.6, p=0.018\right)$ and 8.40 (95\% CI: 3.06 to $23.06 ; \chi^{2}=17.3, p=0.031$ ) times more 
Table 1. Pacifastacus leniusculus. Signal crayfish material and Aphanomyces astaci prevalence in the selected tissues. All 44 individuals originate from ethanol-preserved crayfish collections from the main distribution of signal crayfish in Lake Øymarksjøen. Prevalence of $A$. astaci is given as a percentage of positive tissue samples per individual. Signal crayfish tissue samples include soft cuticle (C), walking legs (L), uropods (U) and melanised spots (S1 and S2). Agent levels A0 to A6 (see specifications in Fig. 5) refer to semi-quantitative categories based on the numbers of observed PCR-forming units (PFU obs) from the $A$. astaci-specific real-time PCR. The estimated number of PFUs based on results from 10-fold dilution templates are given in parentheses. M: male; F: female; NA: test not applicable on symptom-free individuals; -: S2 sample missing; only one spot (S1) observed. Shading visualises agent levels, where darker greys reflect higher agent levels (see Fig. 5)

\begin{tabular}{|c|c|c|c|c|c|c|c|c|}
\hline \multirow{2}{*}{$\begin{array}{l}\text { Case } \\
\text { no. }\end{array}$} & \multirow{2}{*}{ Gender } & \multirow{2}{*}{$\begin{array}{l}\text { Length } \\
(\mathrm{cm})\end{array}$} & \multirow{2}{*}{$\begin{array}{l}\text { Percent } \\
\text { positives }\end{array}$} & \multicolumn{5}{|c|}{ Agent level in crayfish tissues (estimated PFU in PCR) } \\
\hline & & & & $\mathrm{C}$ & $\mathrm{L}$ & $\mathrm{U}$ & $\mathrm{S} 1$ & $\mathrm{~S} 2$ \\
\hline 1 & $\mathrm{~F}$ & 9.7 & 100 & A2 (7) & A3 (389) & A4 (5684) & A6 (502100) & A5 $(23700)$ \\
\hline 2 & $\mathrm{~F}$ & 10.1 & 100 & A3 (166) & A4 (1813) & A4 (6521) & A4 (3166) & - \\
\hline 3 & M & 11.6 & 75 & A1 (2) & A4 (3577) & A3 (292) & A6 (250100) & - \\
\hline 4 & M & 10.6 & 75 & $\mathrm{~A} 0(0)$ & A3 (529) & A4 (2030) & A6 (199900) & - \\
\hline 5 & $\mathrm{~F}$ & 10.8 & 33 & A0 $(0)$ & $\mathrm{A} 0(0)$ & A3 (408) & NA & NA \\
\hline 6 & M & 10.9 & 100 & A2 (13) & A4 (1863) & A4 (4511) & NA & NA \\
\hline 7 & $\mathrm{~F}$ & 10.8 & 50 & $\mathrm{~A} 0(0)$ & A0 (0) & A4 (2166) & A4 (6226) & - \\
\hline 8 & $\mathrm{~F}$ & 9.5 & 100 & A3 625) & A4 (3113) & A5 (20670) & NA & NA \\
\hline 9 & M & 10.4 & 67 & A0 (0) & A4 (1025) & A3 (461) & NA & NA \\
\hline 10 & $\mathrm{~F}$ & 10 & 33 & $\mathrm{~A} 0(0)$ & A0 (0) & A3 (92) & NA & NA \\
\hline 11 & M & 7.1 & 50 & A0 (0) & A0 (0) & A3 (99) & A6 (278400) & - \\
\hline 12 & $\mathrm{~F}$ & 9.6 & 100 & A3 (166) & A3 (166) & A4 (6521) & A4 (9626) & - \\
\hline 13 & M & 10.7 & 100 & A3 (141) & A2 (35) & A3 (264) & NA & NA \\
\hline 14 & M & 10.6 & 60 & A0 (0) & A0 (0) & A3 (103) & A5 (44910) & A4 (3783) \\
\hline 15 & $\mathrm{~F}$ & 10.7 & 100 & A3 (110) & A3 (230) & A4 (1746) & NA & NA \\
\hline 16 & M & 10.6 & 33 & A0 (0) & A0 (0) & A3 (269) & NA & NA \\
\hline 17 & $\mathrm{~F}$ & 11 & 33 & A0 $(0)$ & A0 (0) & A3 (586) & NA & NA \\
\hline 18 & $\mathrm{~F}$ & 9 & 67 & $\mathrm{~A} 0(0)$ & A3 (146) & A4 (1886) & NA & NA \\
\hline 19 & M & 10 & 33 & A0 (0) & $\mathrm{A} 0(0)$ & A3 (894) & NA & NA \\
\hline 20 & $\mathrm{~F}$ & 12.2 & 100 & A3 (120) & A3 (578) & A4 (5956) & NA & NA \\
\hline 21 & $\mathrm{~F}$ & 11.7 & 67 & A0 (0) & A3 (72) & A3 (377) & NA & NA \\
\hline 22 & M & 11 & 67 & A0 (0) & A3 (483) & A3 (620) & NA & NA \\
\hline 23 & M & 7.7 & 100 & A3 (73) & A3 (779) & A3 (299) & NA & NA \\
\hline 24 & M & 7.5 & 0 & A0 (0) & A0 (0) & $\mathrm{A} 0(0)$ & NA & NA \\
\hline 25 & $\mathrm{~F}$ & 10 & 50 & $\mathrm{~A} 0(0)$ & A3 (249) & A4 (7297) & $\mathrm{A} 0(0)$ & - \\
\hline 26 & $\mathrm{~F}$ & 11.5 & 33 & $\mathrm{~A} 0(0)$ & A0 (0) & A3 (338) & NA & NA \\
\hline 27 & $\mathrm{~F}$ & 11.2 & 67 & A0 (0) & A3 (51) & A5 (13320) & NA & NA \\
\hline 28 & M & 11.7 & 100 & A2 (28) & A2 (23) & A3 (393) & NA & NA \\
\hline 29 & $\mathrm{~F}$ & 13.4 & 100 & A3 (291) & A2 (41) & A4 (5914) & NA & NA \\
\hline 30 & $\mathrm{M}$ & 13 & 67 & $\mathrm{~A} 0(0)$ & A3 (873) & A4 (9946) & NA & NA \\
\hline 31 & M & 9.3 & 67 & $\mathrm{~A} 0(0)$ & A2 (20) & A2 (28) & NA & NA \\
\hline 32 & M & 8.9 & 0 & A0 (0) & A0 (0) & A0 (0) & NA & NA \\
\hline 33 & $\mathrm{M}$ & 7.3 & 100 & A2 (14) & A2 (36) & A3 (222) & NA & NA \\
\hline 34 & $\mathrm{M}$ & 8.8 & 0 & $\mathrm{~A} 0(0)$ & $\mathrm{A} 0(0)$ & A0 (0) & NA & NA \\
\hline 35 & $\mathrm{M}$ & 6.8 & 67 & $\mathrm{~A} 0(0)$ & A3 (97) & A2 (39) & NA & NA \\
\hline 36 & $\mathrm{M}$ & 8.1 & 40 & A4 (4678) & A3 (173) & A1 (1) & $\mathrm{A} 0(0)$ & A0 (0) \\
\hline 37 & $\mathrm{M}$ & 7.8 & 0 & $\mathrm{~A} 0(0)$ & $\mathrm{A} 0(0)$ & $\mathrm{A} 0(0)$ & A0 (0) & $\mathrm{A} 0(0)$ \\
\hline 38 & $\mathrm{~F}$ & 13.7 & 75 & A3 (128) & A0 (0) & A4 (2752) & A3 (223) & - \\
\hline 39 & $\mathrm{M}$ & 6.7 & 0 & $\mathrm{~A} 0(0)$ & $\mathrm{A} 0(0)$ & A0 (0) & NA & NA \\
\hline 40 & M & 7.1 & 0 & A0 (0) & $\mathrm{A} 0(0)$ & A0 (0) & $\mathrm{A} 0(0)$ & $\mathrm{A} 0(0)$ \\
\hline 41 & $\mathrm{~F}$ & 14.5 & 100 & A3 (128) & A3 (61) & A4 (2328) & NA & NA \\
\hline 42 & $\mathrm{~F}$ & 14.2 & 100 & A4 (1371) & A3 (641) & A4 (1201) & NA & NA \\
\hline 43 & $\mathrm{~F}$ & 4.2 & 67 & A3 (236) & $\mathrm{A} 0(0)$ & A2 (10) & NA & NA \\
\hline 44 & M & 6.6 & 33 & $\mathrm{~A} 0(0)$ & A0 (0) & A3 (756) & NA & NA \\
\hline
\end{tabular}

likely to detect an $A$. astaci positive crayfish when uropod tissue was used. Of the 38 crayfish that tested positive, uropod samples were positive in 37 out of a total of 38 positive individuals.

Only $12(27.3 \%)$ of the analysed individuals had visible melanised spots that could represent clinical signs of Aphanomyces astaci infection. In 3 individuals, the spot tissue samples were negative. For the 9 remaining individuals, the analysed spots contained moderate to very high levels of agent DNA (cf. Agent Levels A4 to A6; Table 1). Median agent levels were significantly different between positive tissues of $\mathrm{C}, \mathrm{L}$ and $\mathrm{U}(H=$ 


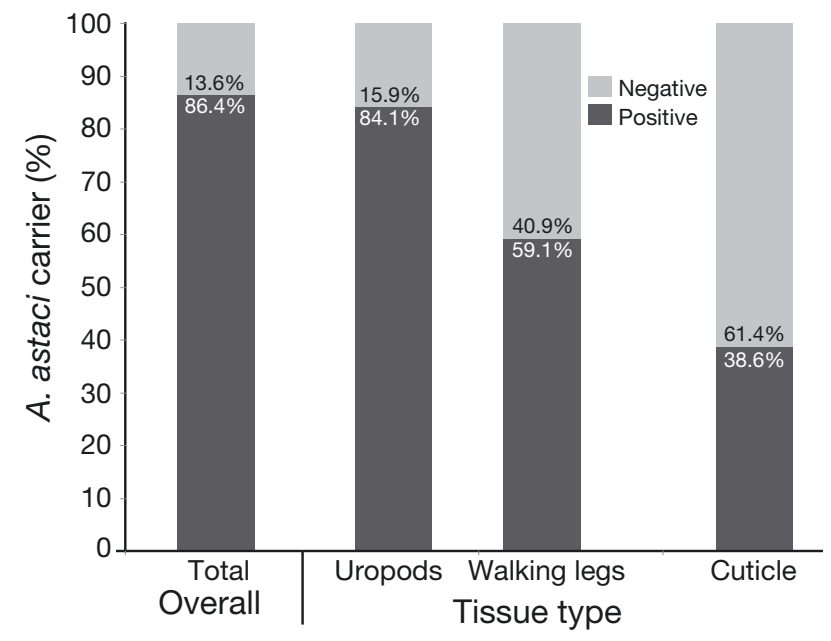

Fig. 4. Pacifastacus leniusculus. Prevalence of Aphanomyces astaci in signal crayfish tissues based on species-specific realtime PCR results. The left bar (total) refers to the overall positive/negative ratio whereby a crayfish individual is regarded as $A$. astaci-positive if one of the tested tissues is positive. The remaining bars show the positive/negative ratios for individual tested crayfish tissues (uropods, walking legs and cuticle). The number of tested crayfish (and individual tissue samples) $=44$

14.5, df $=2, \mathrm{p}<0,001)$. The pairwise comparison showed that the median PFU values in uropod tissues $\left(\mathrm{PFU}_{\text {median }}=756\right)$ were significantly higher compared to those in the tissues from both cuticle $\left(\mathrm{PFU}_{\text {median }}=\right.$ 128) and limbs (PFU median $=239$ ) (Dunn's method, p < 0.05 in both cases; Fig. 5). The middle $50 \%$ of the PFU values cover Agent Levels A3 to A4 for positive uropod samples, and Agent Level A3 for positive cuticle and walking-leg samples (Fig. 5).

\section{DISCUSSION}

In the present study, we demonstrated that the recently discovered signal crayfish Pacifastacus leniusculus population in Norway is well established. The prevalence of Aphanomyces astaci in the populations is high compared to other recent studies (e.g. Kozubikova et al. 2009). Since there are no connecting waterways from Sweden to the lake studied here, the unexpected signal crayfish population evidently results from an illegal, human-assisted transfer. Due to the size and complexity of the watercourse, eradication is unfortunately impossible. Hence this is not only the first established signal crayfish population in Norway, but also represents a potent and permanent reservoir of crayfish plague infection.

The number of Aphanomyces astaci-positive signal crayfish individuals in our study was significantly higher based on analyses of uropod tissue compared to

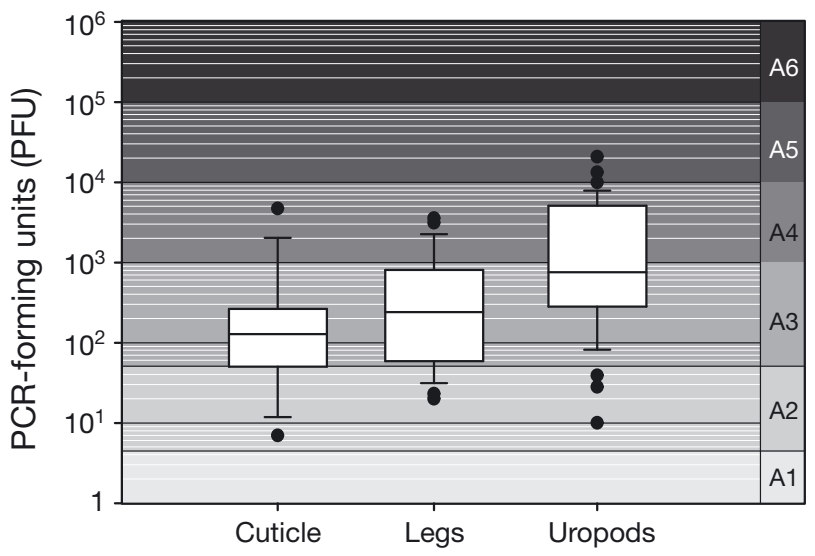

Fig. 5. Pacifastacus leniusculus. Box and whisker plot showing PCR-forming unit (PFU)-values from real-time PCR analyses of positive crayfish tissue samples; soft abdominal cuticle $(n=17)$, walking legs $(n=26)$ and uropods $(n=37)$. The boxes include the middle $50 \%$ of the PFU-values, and the vertical lines show the 10th and 90th percentiles. Filled circles represent PFU-values outside this range. The median is shown by the unbroken horizontal line within the boxes. Agent levels are indicated and refer to semi-quantitative categories based on the numbers of observed PFUs ( $\mathrm{PFU}_{\mathrm{obs}}$ ) in the PCR. Agent Level 1 (A1): below detection limit $\left(\mathrm{PFU}_{\text {obs }}<5\right)$; $\mathrm{A} 2$ : $5 \leq \mathrm{PFU}_{\text {obs }}$ $<50$; A3: $50 \leq \mathrm{PFU}_{\text {obs }}<10^{3}$; A4: $10^{3} \leq \mathrm{PFU}_{\text {obs }}<10^{4}$; A5: $10^{4} \leq$ $\mathrm{PFU}_{\text {obs }}<10^{5}$; $\mathrm{A} 6: 10^{5} \leq \mathrm{PFU}_{\text {obs }}<10^{6}$ (according to Vrålstad et

al. 2009). Darker shading reflects higher agent levels

analyses of soft abdominal cuticle and walking legs. This contradicts previously reported results (Oidtmann et al. 2006) in which cuticle and tail fan tissue gave approximately equal detection probabilities. Oidtmann et al. (2006) referred only to the term 'telson', but their analyses included both uropod and telson tissue from the tail fan. We undoubtedly failed to detect some A. astaci in the cuticle, since we used only one-half. However, detection in $>84 \%$ of the crayfish individuals using three-fifths of the outer tail fan, and the significantly higher PFU levels in tail fan tissue compared to cuticle and walking-leg tissues, support this tissue (including uropods and telson) as being a more reliable choice for both routine analyses and large-scale prevalence studies. We did not consider tissue weight, but analysed instead standardised tissue samples in which a standard uropod sample has higher weight than a corresponding cuticle sample (up to a factor of 1.6; authors' unpubl. data). The higher PFU levels in the uropods are therefore partly a result of the greater amount of tissue analysed, but even doubling the tissue weight cannot explain the observed difference. Further, the significant difference in PFU levels between cuticle, legs and uropods resulted from a test of solely positive samples. If negative samples had been taken into account, the difference in median PFU levels would have been considerably larger in favour of the uropod samples. While PFU levels compared to 
sample weight may be of limited interest, due to the expected uneven infection sites of the tissues, the total surface area may be of more significance. The soft cuticle is only exposed to infective zoospores from one side. In contrast, the tail fan, including uropods and telson, is not only exposed to infections from above and below, but offers also a considerably larger total exposure area, due to additional micro-surfaces arising from the rough and almost hairy character of the tissue. The area exposed to infection is therefore assumedly much larger in tail fan tissue compared to soft cuticle tissue of a corresponding weight.

In a recent study from Denmark, no Aphanomyces astaci at all were detected using the same tissue samples and molecular analyses on a total of 44 signal crayfish (Skov et al. 2010). The carrier status of signal crayfish therefore seems to vary considerably between populations, and the traditional view that all signal crayfish are chronic carriers has been challenged in several recent studies (Oidtmann et al. 2006, Kozubikova et al. 2009, 2010, Skov et al. 2010). It is important to bear in mind, though, that some of the recent prevalence reports solely rely on semi-nested PCR analysis (Oidtmann et al. 2006) of the soft abdominal cuticle tissues (Kozubikova et al. 2009), i.e. both the molecular approach used and choice of tissue may increase the risk of false negatives.

Studies on the prevalence of Aphanomyces astaci within a crayfish population should, in general, aim at sampling crayfish randomly. However, routine analyses or studies between populations (e.g. Kozubikova et al. 2009) often seek primarily to clarify whether or not a population is likely to be infected before extra effort is invested in a general evaluation of the $A$. astaci prevalence in the population. Concluding that a population is free of infection is practically impossible. However, the results from our study suggest that large female signal crayfish should be selected in surveys if the prime goal is detection of $A$. astaci-positive individuals. They may also be taken into consideration when modelling how many analysed individuals are needed to assume a population is free of infection, e.g. with $95 \%$ confidence. The observed increased probability of detecting $A$. astaci in larger crayfish in general, and large females in particular, probably reflects the decreased moult frequency of larger mature individuals compared to smaller immature crayfish (Reynolds 2002), whereby mature females tend to moult even less frequently than mature males (Skurdal \& Qvenild 1986). Decreased moulting frequency results in longer exposure times of the exoskeleton to repeated $A$. astaci infections, and further spread of the parasite from each infection point. This is in concordance with the recent study by Aquiloni et al. (2010), in which a positive relationship was observed between crayfish size and number of micro-melanised spots (confirmed A. astaci) in the soft abdominal cuticle of the invasive crayfish species Procambarus clarkii.

In apparently healthy signal crayfish individuals, the infection with Aphanomyces astaci is usually invisible or may be seen in the microscope as minute, melanised spots on the crayfish exoskeleton (Söderhäll \& Cerenius 1999). In some cases, the parasite may cause larger, easily recognised melanised areas. In our study, only $27 \%$ of the examined individuals exhibited at least one melanised spot that could represent a clinical sign of $A$. astaci infection. In all but 3 small male individuals, in which the spots presumably resulted from other factors or agents, the RT-PCR analysis detected high levels of A. astaci DNA for the spot samples. This is expected if a spot represents an accumulation of agent tissue relative to crayfish tissue. In the other, symptom-free tissue samples, the amount of crayfish tissue relative to potential agent tissue is presumably much higher. Thus, visible spots may have a limited predictive value for the evaluation of carrier status in signal crayfish. However, we only observed melanised spots visible by eye. Aquiloni et al. (2010) detected A. astaci on a molecular level in all soft abdominal cuticle samples of Procambarus clarkii that contained micro-melanised spots, targeted by the use of digital image analyses and image processing techniques. This targeted approach for selection of suitable tissues should also be considered for signal crayfish prevalence studies.

Westman et al. (2002) demonstrated that noble crayfish Astacus astacus and signal crayfish Pacifastacus leniusculus share similar habitat preferences. Before the first outbreak of crayfish plague in 1989, Lake Øymarksjøen hosted a large population of noble crayfish (Taugbøl et al. 1993), suggesting that the abiotic and biotic environments of this lake are also ideal for signal crayfish. The length distribution, relative density, total number captured and spread of signal crayfish demonstrates a well-established population where the introduction may date as far back as a decade. The smallest captured individuals of signal crayfish in the lake (individuals $<90 \mathrm{~mm}$ ) were most likely naturally recruited, since signal crayfish may reach these lengths over a period of 3 to 4 yr (Abrahamsson 1970, 1971). In retrospect, it seems evident that Aphanomyces astaci-carrying signal crayfish caused the severe outbreak of crayfish plague in the lake and further downstream the Halden watercourse during summer 2005 (Vrålstad et al. 2006). It cannot be excluded that their presence is also linked to the outbreak in 1989. However, strong circumstantial evidence suggests that the infection in 1989 was transmitted by boats or gear from the neighbouring Lake Store Le, which suffered an explosive outbreak only a few 
weeks before the Halden watercourse was struck (Taugbøl et al. 1993).

Introduction of non-indigenous crayfish has always been prohibited according to Norwegian legislation, and crayfish plague is a disease (List 3-national diseases) with strict national legislation practices. The establishment of an Aphanomyces astaci-carrying signal crayfish population in Norway is therefore a danger to the noble crayfish population in Europe in general and in Norway in particular. Nevertheless, compared to most other European countries, the problem is still manageable. Although general attempts to eliminate signal crayfish populations in European countries have proven difficult (Kozac \& Polizar 2003, Holdich et al. 2009), the first discovered population of signal crayfish in Norway (Johnsen et al. 2007) was most likely eradicated after intensive effort by the combined usage of cypermetrin and draining (Sandodden \& Johnsen 2010). Even though such actions are ecologically, economically and practically inconceivable in the current case, due to the size and complexity of the watercourse, the authorities have the situation under relatively good control. The probability of a further spread of the signal crayfish population and the accompanying crayfish plague infection has been reduced to a minimum by strict regulations. These include mandatory disinfection of boats and gear, a ban on any exploitation of signal crayfish, and permanent closure of the Ørje locks (Johnsen \& Vrålstad 2009). The latter has proven an efficient physical infection barrier between the signal crayfish of Lake Øymarksjøen and the noble crayfish of the upstream Lake Rødenessjøen. The main challenge is therefore to avoid further illegal, human-assisted spread. It is therefore vital to work in close collaboration with local authorities and the general public to prevent a growing population of signal crayfish in the lake that could act as a donor population to nearby water localities.

Acknowledgements. The present study was funded by the Norwegian Research Council (Project Number NFR-183986) through the research programme Norwegian environmental research towards 2015 (MILJØ 2015), and the Directorate for Nature Management. We thank Jørn Daltorp and Øystein Toverud for valuable assistance during the fieldwork.

\section{LITERATURE CITED}

Abrahamsson S (1970) Distribution, density and production of the crayfish Pasifastacus leniusculus Dana in Lake Tahoe, California-Nevada. Oikos 21:83-91

Abrahamsson S (1971) Density, growth and reproduction in populations of Astacus astacus and Pasifastacus leniusculus in an isolated pond. Oikos 22:373-380

- Alderman DJ, Holdich D, Reeve I (1990) Signal crayfish as vectors in crayfish plague in Britain. Aquaculture 86:3-6
Aquiloni L, Martin MP, Gherardi F, Dieguez-Uribeondo J (2010) The North American crayfish Procambarus clarkii is the carrier of the oomycete Aphanomyces astaci in Italy. Biol Invasions 13:359-367

Bohman P, Nordwall F, Edsman L (2006) The effect of the large-scale introduction of signal crayfish on the spread of crayfish plague in Sweden. Bull Fr Peche Piscic 380/381: 1291-1302

Edsman L (2004) The Swedish story about import of live crayfish. Bull Fr Peche Piscic 372/373:281-288

Edsman L, Füreder L, Gherardi F, Souty-Grosset C (2010) Astacus astacus. In: IUCN red list of threatened species, Version 2010.4. International Union for Conservation of Nature and Natural Resources, Gland

Holdich DM, Reynolds JD, Souty-Grosset C, Sibley PJ (2009) A review of the ever increasing threat to European crayfish from non-indigenous crayfish species. KMAE 394/395: 11

Johnsen SI, Vrålstad T (2009) Signalkreps og krepsepest i Haldenvassdraget - forslag til tiltaksplan. NINA Rapport 474, Norsk institutt for naturforskning (NINA), Lillehammer

Johnsen SI, Taugbol T, Andersen O, Museth J, Vrålstad T (2007) The first record of the non-indigenous signal crayfish Pasifastacus leniusculus in Norway. Biol Invasions 9: 939-941

Kozac P, Polizar T (2003) Practical elimination of signal crayfish, Pasifastacus leniusculus (Dana), from a pond. In: Holdich DM, Sibley PJ (eds) Management and conservation of crayfish. Proceedings of a conference held on 7th November, 2002. Environment Agency, Bristol, p 217

Kozubikova E, Filipova L, Kozak P, Duris Z and others (2009) Prevalence of the crayfish plague pathogen Aphanomyces astaci in invasive American crayfishes in the Czech Republic. Conserv Biol 23:1204-1213

Kozubikova E, Puky M, Kiszely P, Petrusek A (2010) Crayfish plague pathogen in invasive North American crayfish species in Hungary. J Fish Dis 33:925-929

Oidtmann B, Geiger S, Steinbauer P, Culas A, Hoffmann RW (2006) Detection of Aphanomyces astaci in North American crayfish by polymerase chain reaction. Dis Aquat Org 72:53-64

Oug E, Brattegard T, Vader W, Christiansen M, Walseng B, Djursvoll P (2010) Crustacea. In: Kålås J, Viken Å, Henriksen S, Skjelseth S (eds) 2010 Norwegian Red List for Species. Norwegian Biodiversity Information Centre, Norway, p 209-222

Pöckl M, Holdich DM, Pennerstorfer J (2006) Identifying native and alien crayfish species in Europe. European Project CRAYNET, Guglar Cross Media, Melk

Reynolds JD (2002) Growth and reproduction. In: Holdich DM (ed) Biology of freshwater crayfish. Blackwell Science, Oxford, p 152-191

Sandodden R, Johnsen S (2010) Eradication of introduced signal crayfish Pasifastacus leniusculus using the pharmaceutical BETAMAX VET ${ }^{\circledR}$. Aquat Invasions 5:75-81

Skov C, Aarestrup K, Sivebæk F, Pedersen S, Vrålstad T, Berg S (2010) Non-indigenous signal crayfish Pacifastacus leniusculus are now common in Danish streams: preliminary status for national distribution and protective actions. Biol Invasions 13:1269-1274

Skurdal J, Qvenild T (1986) growth, maturity and fecundity of Astacus astacus in Lake Steinsfjorden, S.E. Norway. Freshw Crayfish 6:182-186

Söderhäll K, Cerenius L (1999) The crayfish plague fungus: history and recent advances. Freshw Crayfish 12:11-35 
Souty-Grosset C, Holdich DM, Noël PY, Reynolds JD, Haffner $P$ (2006) Atlas of crayfish in Europe. Museum national d'Historie naturelle, Paris

Taugbøl T (2004) Reintroduction of noble crayfish Astacus astacus after crayfish plague in Norway. Bull Fr Peche Piscic 372/373:315-328

Taugbøl T, Skurdal J, Håstein T (1993) Crayfish plague and management strategies in Norway. Biol Conserv 63:75-82

Unestam T (1972) On the host range and origin of the crayfish plague fungus. Rep Inst Freshw Res Drottningholm 52: 192-198

Vrålstad T, Håstein T, Taugbøl T, Lillehaug A (2006) Krepsepest-smitteforshold i norske vassdrag og fore-

Editorial responsibility: Grant Stentiford, Weymouth, UK byggende tiltak mot videre spredning av krepsepest. Veterinærinstituttets rapportserie 6:1-25. Available at: www. vetinst.no/nor/content/download/505/4141/file/Rapport_ 06_2006.pdf

Vrålstad T, Knutsen AK, Tengs T, Holst-Jensen A (2009) A quantitative TaqMan (R) MGB real-time polymerase chain reaction based assay for detection of the causative agent of crayfish plague Aphanomyces astaci. Vet Microbiol 137: 146-155

Westman K, Savolainen R, Julkunen M (2002) Replacement of the native crayfish Astacus astacus by the introduced species Pacifastacus leniusculus in a small, enclosed Finnish lake: a 30-year study. Ecography 25:53-73

Submitted: April 11, 2011; Accepted: June 27, 2011

Proofs received from author(s): September 23, 2011 